\title{
Subject Unblinding
}

National Cancer Institute

\section{Source}

National Cancer Institute. Subject Unblinding. NCI Thesaurus. Code C82524.

An indication or description that a previously masked component of a study is revealed to the individual taking part in the study. 